\title{
Tumor necrosis factor alpha -308 promoter polymorphism and insulin resistance in overweight and obese adolescents
}

\author{
Polimorfismo do promotor -308 do fator de necrose tumoral alfa e resistência à insulina \\ em adolescentes com sobrepeso e obesidade
}

Carlos Alberto Menezes ${ }^{1}$, Luís Jesuíno de Oliveira Andrade ${ }^{1}$, Jordian Jorge Pinheiro², Gustavo Soares Correia², Paulo Roberto Santana de Melo ${ }^{3}$, Fabrício Rios-Santos ${ }^{4}$

\begin{abstract}
Study Model/Methodology: This is a cross-sectional study with a sample of 104 overweight/obese adolescents, with a mean weight of $52.98 \mathrm{~kg} \pm 22.00$, mean age $16.01 \pm 2.91$ years. We used the homeostasis model assessment-estimated IR (HOMA-IR) index to quantify the insulin resistance (IR). The -308 polymorphism of the promoter of TNF- $\alpha$ was performed using polymerase chain reactionrestriction fragment length polymorphism technique. Statistical analysis of the quantitative measures was conducted with a student's t-test. For correlation between the genotype and alleles, we used chisquare statistical test. To test the heterogeneity between HOMA-IR and the anthropometric parameters the Mann-Whitney test was used, associated with the Hardy-Weinberg equilibrium. The association between -308G/A polymorphism of the promoter of TNF- $\alpha$ and HOMA-IR was tested by univariate linear regression analysis. Objective: Investigate the association between -308G/A polymorphism in the promoter of tumor necrosis factor-alpha (TNF- $\alpha$ ) and susceptibility to IR in overweight/obese adolescents. Results: The prevalence of IR was $18.30 \%$ according to the HOMA-IR. The frequency of GG, AG and AA genotype was found $75(72.12 \%), 28(26.92 \%)$ and $1.0(0.96 \%)$ respectively. Allele frequencies for guanine $(\mathrm{G})$ and adenine $(A)$ were $178(85.58 \%)$ and $30(14.42 \%)$, respectively. The allele $A$ as well as GA and AA genotype contributed to increase RI ( $14.42 \%$ and $27.88 \%$ respectively). Conclusion: The $308 \mathrm{G} / \mathrm{A}$ polymorphism of the promoter of TNF- $\alpha$ can contribute to the IR increase in obese adolescents with GA and AA genotypes.
\end{abstract}

Keywords: Obesity. Adolescents. polymorphism, Tumor Necrosis Factor-alpha. Insulin Resistance.

1. Docente, Disciplina de Endocrinologia e Metabologia da Faculdade de Medicina da Universidade Estadual de Santa Cruz (FM-UESC). Ilhéus, Bahia.

2. Graduando em Medicina, Faculdade de Medicina, FM-UESC.

3. Docente, Departamento de Ciências Biológicas - Universidade Estadual de Santa Cruz - UESC - Ilhéus - Bahia Brazil.

4. Docente, Departamento de Farmacologia da Universidade Federal de Mato Grosso- UFMT.
CORRESPONDÊNCIA: Carlos Alberto Menezes Universidade Estadual de Santa Cruz. Colegiado de Medicina. Campus Soane Nazaré de Andrade, Rodovia Jorge Amado, Km 16, Bairro Salobrinho Zip Code 45662-900. Ilhéus-Bahia-Brasil

Recebido em 07/08/2017 Aprovado em 27/02/2018 


\begin{abstract}
RESUMO
Modelo de Estudo / Metodologia: Trata-se de um estudo transversal, com uma amostra de 104 adolescentes com sobrepeso/ obesidade, com peso médio de $52,98 \mathrm{~kg} \pm 22,00$, média de idade de $16,01 \pm 2,91$ anos. Utilizamos o índice estimado (HOMA-IR) do modelo de homeostase para quantificar a resistência insulínica (RI). 0 polimorfismo do promotor -308 do TNF- $\alpha$ foi realizado utilizando a técnica de polimorfismo de comprimento de fragmento de restrição. A análise estatística das medidas quantitativas foi realizada com o teste $t$ student. Para a correlação entre o genótipo e os alelos, utilizamos o teste estatístico qui-quadrado. Para testar a heterogeneidade entre HOMA-IR e os parâmetros antropométricos foi utilizado o teste de Mann-Whitney associado ao equilíbrio de Hardy-Weinberg. A associação entre o polimorfismo -308G/A do promotor do TNF- $\alpha$ e HOMA-IR foi testada por análise de regressão linear univariada. Objetivo: investigar a associação entre o polimorfismo -308G/A no promotor do fator de necrose tumoral alfa (TNF- $\alpha$ ) e a susceptibilidade à RI em adolescentes com sobrepeso/ obesidade. Resultados: A prevalência de RI foi de $18,30 \%$ de acordo com o HOMA-IR. A frequência dos genótipos GG, AG e AA encontrados foram $75(72,12 \%), 28(26,92 \%)$ e $1,0(0,96 \%)$, respectivamente. As frequências de alelos para guanina $(G)$ e adenina $(A)$ foram 178 (85,58\%) e $30(14,42 \%)$, respectivamente. $O$ alelo $A$, bem como o genótipo GA e AA, contribuíram para aumentar o RI (respectivamente $14,42 \%$ e $27,88 \%$ ). Conclusão: $O$ polimorfismo -308 G / A do promotor do TNF- $\alpha$ pode contribuir para o incremento de RI em adolescentes sobrepesos/obesos com genótipos GA e AA.
\end{abstract}

Palavras chaves: Obesidade. Adolescentes. polimorfismo, Fator de Necrose Tumoral alfa. Resistência à Insulina.

\section{Introduction}

Tumor necrosis factor-alpha (TNF- $\alpha$ ) is a potent central mediator and pro-inflammatory cytokine implicated in the immunological response that has been associated with a large number of human diseases. ${ }^{1,2}$ The activation of the immune system during infection or injury leads to widespread metabolic changes. There is a trend on increasing secretion of cytokines that has been implicated in the etiology of insulin resistance (IR) and other components of the metabolic syndrome, such as glucose intolerance, obesity, dyslipidemia, and high blood pressure. $^{3}$

The increase in the plasma concentration of TNF- $\alpha$ induces IR states of obesity and type 2 diabetes mellitus (DM2). ${ }^{4}$ Two mechanisms might be involved in the pathogenesis of inflammation. One would be oxidative stress and inflammatory changes resulting from glucose and macronutrient intake, and the other concerns the increased concentrations of TNF- $\alpha$ itself which would interfere with insulin action by suppressing insulin signal transduction. This might interfere with the anti-inflammatory effect of insulin, which in turn might promote inflammation. ${ }^{5}$ The polymorphism at position -308 in the promoter region of the TNF- $\alpha$ gene may lead to its increased transcription in adipocytes, and involving a single base change $(-308 \mathrm{G} / \mathrm{A})$, in the promoter region, this variant have been linked to IR and obesity in different ethnic groups. ${ }^{6}$ It is important to note that the TNF- $\alpha$ gene is located in the chromosomal region 6p21.1-21.3, next to the major histocompatibility complex. ${ }^{7}$

Overweight and obesity in childhood often precedes the hyperinsulinemic state. ${ }^{8}$ There is evidence in literature that being overweight during childhood and adolescence is significantly associated to metabolic syndrome. ${ }^{9}$

During puberty there a physiological increase in insulin levels which has not yet been clearly clarified, and a transient IR develops during puberty, being accepted as physiological condition. ${ }^{10,11} \mathrm{How}$ ever, homeostasis model assessment HOMA-IR demonstrated that obese children with HOMA-IR > 3.16 are regarded carriers of IR non-physiological. ${ }^{12,13}$

The TNF- $\alpha$ expression is linked with IR, and is under tight genetic control. Based on this premise this study aims to investigate the association of the -308 polymorphism of the promoter region of TNF- $\alpha$ $(-308 \mathrm{G} / \mathrm{A})$ with susceptibility to IR in overweight and obese adolescents. 


\section{Methods}

\section{Sample collection}

After approval of the study by the ethic committee of the State University of Santa Cruz, Ilhéus - Bahia - Brazil, under the presentation of Certificate for Ethics Assessment (CAAE) 04065412.600005526 of Brazil platform the parents provided informed written consent for younger than 18 years provided the assent to participate in this study. Those with an underlying endocrinologic disease or/and those under medication were excluded of the study.

The sample consisted of 104 consecutive overweight and obese adolescents. After obtaining informed parental consent, $10 \mathrm{ml}$ of peripheral blood was collected and stored at $-20^{\circ} \mathrm{C}$.

\section{Anthropometric measurements}

Standardized protocols and calibrated equipment were used to obtain measurement of height, weight, and waist circumference (WC).

The weight measuring procedures: the scale is set at zero reading scale is set on firm surface, removes shoes and heavy outer clothing and empties pockets, steps on center of the platform, with back toward the scale, both feet on platform. The height measuring procedures: removes shoes, removes hair ornaments, buns, braids to extent possible, stands on foot plate portion with back against stadiometer rule. The WC was measured in $\mathrm{cm}$ with a fiberglass tape with tension gauge, with the subject standing, feet slightly apart, and abdomen relaxed, a horizontal measure was taken at the narrowest point of the torso above the umbilicus and below the ribcage.

A worldwide standardization of WC is warranted and adult cut-off values were defined. However, children and adolescents no uniform definition of WC cut-offs exists in function of physiological growth and development. The Brazilian-IranianGerman (BIG) Study compared children ( 6 to $<10$ years) and adolescents (10 to $<16$ years) participating in the Belo Horizonte Heart Study in Brazil, and the mean values of WC were for children $59.2 \pm 7.2 \mathrm{~cm}$ (males) and $58.0 \pm 6.8 \mathrm{~cm}$ (females), and adolescents $68.4 \pm 10.0 \mathrm{~cm}$ (males) and $65.7 \pm 8.1 \mathrm{~cm}$ (females). ${ }^{14}$ Body mass index (BMI) of the patients was calculated using the equation: BMI $=$ Body weight $(\mathrm{Kg}) /$ Height $\left(\mathrm{m}^{2}\right)$. Subjects whose BMI values were above $85 \%$ in the BMI reference curve, regarding age and gender, were considered to be overweight and subjects whose BMI values were above $95 \%$ in the BMI reference curve, were considered obese. BMI z-score were then calculated from the 2000 CDC and 2007 WHO data, which classified them overweight $(z$-score $\geq 1$ and $<2$ ) or obese (BMI z-score $\geq 2$ ). The WC was higher assessed in the 90th percentile. ${ }^{15}$

\section{Blood sampling and laboratory assays}

DNA extraction: DNA extraction was performed using FlexiGene DNA Kit $®$ (Qiagen, California, USA) and stored at $20^{\circ} \mathrm{C}$ negative. The genotyping was performed using polymerase chain reaction-restriction fragment length polymorphism (PCR-RFLP) technique according to a previously published method. ${ }^{16}$

Biochemical variables: After an overnight fasting, blood was collected between 7 and 10AM in a 1-g/L EDTA collection tube and placed on ice. Samples were centrifuged for $45 \mathrm{~min}$, transported on dry ice, and stored at $-80^{\circ} \mathrm{C}$. Plasma glucose levels were measured by the glucose oxidase method and the modified Trinder color reaction catalyzed by the peroxidase enzyme, with reference value $70-99 \mathrm{mg} / \mathrm{dl}$. Insulin levels were measured with an immunoradiometric assay kit (INS-Irma Biosource, Nivelles, Belgium). The assay detection limit was $1 \mu \mathrm{U} / \mathrm{mL}$, and intra- and interassay coefficients of variation were $2.2 \%$ and $6.5 \%$, respectively, with reference value $28.4 \mu \mathrm{U} / \mathrm{ml}$. The HOMAIR, whereby an increase in value signifies an increase in IR, was calculated using the equation: HOMA-IR=Fasting insulin $(\mu \mathrm{U} / \mathrm{mL}) \times$ Fasting glucose $(\mathrm{mg} / \mathrm{dL}) / 405 .{ }^{17,18}$ HOMA-IR higher than 3.16 was considered as insulin resistant. ${ }^{12,13}$

\section{Statistical analysis}

Statistical analysis of the quantitative measures was conducted with the student's t-test. For correlation between the genotype and alleles, we used chi-square statistical test. To test the heterogeneity between HOMA-IR and the anthropometric parameters the Mann-Whitney test as used between groups of boys e and girls. We used the HardyWeinberg to calculate the allelic equilibrium. 
The association between -308G/A polymorphism of the promoter of TNF- $\alpha$ and HOMA-IR was tested by univariate linear regression analysis. Data distributions were tested for parametric and nonparametric by use of student's t-test.

Normally distributed data were expressed as mean. The level of statistical significance accepted as $\mathrm{p}<0.05$.

\section{Results}

A total of 104 adolescents with overweight and obesity ( 46 girls, 58 boys) were included in the study. The mean age was $16.01 \pm 2.91$ (16-18) years, mean weight of $52.98 \pm 2.2 \mathrm{~kg}$, and mean BMI $23.31 \pm 6.83 \mathrm{~kg} / \mathrm{m}^{2}$ (Table 1 ).

The frequency of GG, GA and AA genotype was found to be $75(0.7212), 28(0.2692)$ and 1
(0.0096) respectively. Allele frequencies for guanine $(G)$ and adenine (A) were found to be 178 $(0.8558)$ and $30(0.1442)$ respectively.

The distribution of the genotypes and the alleles of the TNF- $\alpha$ gene are presented in Table 2 . The TNF- $\alpha$ ( -308 GA and GG) genotype distribution varied between the girls $(27.1 \%$ and $71.7 \%)$ and boys $(26.7 \%$ and $72.4 \%)$ respectively. The percentage of the genotypes GG homozygote was $72.4 \%$ and GA heterozygotes were $27.9 \%$.

TNF- $\alpha-308 \mathrm{G} / \mathrm{A}$ genotype distribution and anthropometrical parameters in studied individuals are presented in Table 3. The presence of IR according to HOMA-IR $\geq 3.16$ was identified in $18.30 \%$ of obese subjects. This HOMA-IR limit was exceeded by 7 girls and 10 boys. The aspects of biochemical variables HOMA-IR and anthropometrical parameters in studied individuals are shown in Table 4.

Table 1: The clinical characteristics of the group of overweight and obese boys and girls

\begin{tabular}{|c|c|c|c|c|c|c|}
\hline & \multicolumn{2}{|c|}{$\begin{array}{c}\text { Boys } \\
n=58\end{array}$} & \multicolumn{2}{|c|}{$\begin{array}{c}\text { Girls } \\
n=46\end{array}$} & \multicolumn{2}{|c|}{$\begin{array}{c}\text { Total } \\
n=104\end{array}$} \\
\hline & mean $\pm S D$ & Range & mean $\pm S D$ & Range & mean \pm SD & Range \\
\hline Age (years) & $15.37 \pm 2.98$ & $15.0-18.0$ & $16.07 \pm 2.66$ & $16.0-18.0$ & $16.01 \pm 2.91$ & $16.0-18.0$ \\
\hline Weight (kg) & $56.64 \pm 2.4 \quad 5$ & $50.0-124.0$ & $48.18 \pm 1.7$ & $47.0-95.0$ & $52.98 \pm 2.24$ & $47.0-124.0$ \\
\hline Height (m) & $1.51 \pm 0.16$ & $1.45-1.77$ & $1.45 \pm 0.13$ & $1.46-1.70$ & $1.48 \pm 0.15$ & $1.15-1.77$ \\
\hline$B M I\left(K g / m^{2}\right)$ & $23.95 \pm 2.98$ & $18.8-45.0$ & $22.48 \pm 5.82$ & $18.70-37.1$ & $23.31 \pm 6.83$ & $18.70-45.0$ \\
\hline
\end{tabular}

BMI: Body mass index, Range: minimum - maximum values

Table 2. Polymorphism frequency in boys and girls overweight and obesity

\begin{tabular}{|c|c|c|c|c|c|c|c|}
\hline & \multicolumn{7}{|c|}{-308 polymorphism of the promoter of TNF- $\alpha$} \\
\hline & \multicolumn{4}{|c|}{ Genotypes } & \multicolumn{3}{|c|}{ Allele } \\
\hline & GG & GA & AA & & $\mathbf{A}$ & $\mathbf{G}$ & \\
\hline & n / \% & n / \% & n / \% & P value & n \% & n \% & P value \\
\hline $\mathrm{n}=104$ & $75 / 72.4$ & $28 / 26.9$ & $1 / 1.0$ & & $30 / 14.4$ & $178 / 85.6$ & $0.084^{c}$ \\
\hline Boys & $42 / 72.4$ & $16 / 27.6$ & $0 / 0$ & $0.006^{a}$ & $16 / 13.8$ & $100 / 86.2$ & \\
\hline Girls & $33 / 71.7$ & $12 / 27.1$ & $1 / 0.96$ & $0.004^{\mathrm{b}}$ & $14 / 15.2$ & $78 / 86.2$ & \\
\hline
\end{tabular}

apearson $\div^{2}$ analysis, ÁÁ vs GG/GA, ${ }^{b}$ Pearson $\div^{2}$ analysis ÁÁ/GA vs GG, ${ }^{c}$ controlled for sex, $B M I$ with the use of regression analysis 
Table 3. TNF- $\alpha$-308G/A genotype distribution and anthropometrical parameters in studied overweight and obese boys and girls.

\begin{tabular}{|c|c|c|c|}
\hline & $\begin{array}{c}\text { TNF-alpha } \\
\text {-308 G>A } \\
\text { GG } \\
\text { Median } \pm \text { SD }\end{array}$ & $\begin{array}{c}\text { TNF-alpha } \\
\text {-308 G>A } \\
\text { GA + AA } \\
\text { Median } \pm \text { SD }\end{array}$ & P value* \\
\hline Height $(\mathrm{cm})$ & $151.00 \pm 14.43$ & $159.00 \pm 13.67$ & 0.851 \\
\hline Weight $(\mathrm{Kg})$ & $66.00 \pm 20.61$ & $66.50 \pm 22.15$ & 0.707 \\
\hline Waist circumference $(\mathrm{cm})$ & $90.00 \pm 11.18$ & $92.00 \pm 14.97$ & 0.940 \\
\hline Body mass index $\left(\mathrm{Kg} / \mathrm{m}^{2}\right)$ & $28.25 \pm 5.11$ & $28.67 \pm 5.68$ & 0.679 \\
\hline
\end{tabular}

SD, Standard Deviation, * Mann-Whitney test.

Table 4. HOMA-IR and anthropometrical parameters in studied individuals.

\begin{tabular}{lcccc}
\hline & $\begin{array}{c}\text { Height } \mathbf{( c m )} \\
\text { Median } \pm \text { SD }\end{array}$ & $\begin{array}{c}\text { Weight } \mathbf{( K g )} \\
\text { Median } \pm \text { SD }\end{array}$ & $\begin{array}{c}\text { Abdominal } \\
\text { circumference }(\mathbf{c m}) \\
\text { Median } \pm \text { SD }\end{array}$ & $\begin{array}{c}\text { Body mass) } \\
\text { index }\left(\mathbf{K g} / \mathbf{m}^{2}\right. \\
\text { Median } \pm \text { SD }\end{array}$ \\
\hline $\begin{array}{l}\text { Blood glucose } \\
<99 \mathrm{mg} / \mathrm{dL}\end{array}$ & $144 \pm 13.73$ & $56.70 \pm 18.52$ & $87.00 \pm 12.51$ & $26.82 \pm 4.73$ \\
$\geq 99 \mathrm{mg} / \mathrm{dL}$ & $155.5 \pm 14.91$ & $73.00 \pm 22.68$ & $93.00 \pm 11.64$ & $29.27 \pm 5.36$ \\
$P$ value* & 0.001 & 0.001 & 0.001 & 0.005
\end{tabular}

\section{HOMA-IR}

$\begin{array}{lcccc}<3.16 & 143 \pm 13.55 & 56.00 \pm 18.44 & 87.00 \pm 10.74 & 26.70 \pm 4.37 \\ \geq 3.16 & 150 \pm 14.80 & 61.25 \pm 20.76 & 89.50 \pm 14.98 & 27.45 \pm 5.59 \\ P \text { value* } & 0.010 & 0.014 & 0.021 & 0.143\end{array}$

\section{Insulin}

$\begin{array}{lcccr}<24.9 \mathrm{mU} / \mathrm{L} & 145 \pm 14.26 & 57.50 \pm 19.77 & 88.00 \pm 12.67 & 27.02 \pm 4.93 \\ \geq 24.9 \mathrm{mU} / \mathrm{L} & 143.5 \pm 13.21 & 60.50 \pm 15.44 & 89.50 \pm 11.94 & 28.32 \pm 4.22 \\ P \text { value* } & 0.399 & 0.795 & 0.749 & 0.893\end{array}$

$\mathrm{SD}$, Standard Deviation, * Mann-Whitney test.

The alleles $G$ and $A$, as well as $G G$ and $G A / A A$ genotype, contributed to an increase of RI ( $85.58 \%$ and $14.42 \%$ as $72.12 \%$ and $27.88 \%$ respectively). Subjects with AA and GA genotypes had significantly higher levels of HOMA-IR, ( $p$ 0.034) than those carrying GG genotype. HOMA-IR in subjects with AA and $A G$ were greater than those with $G G$ genotype in boys and girls (Table 5 ).

\section{Discussion}

The present study investigated the relationship between TNF- $\alpha-308$ G/A polymorphisms promoter and the susceptibility to IR in overweight and obese children and adolescents. The results revealed a significant association of the TNF- $\alpha-308 \mathrm{G} / \mathrm{A}$ polymorphism promoter with IR. The association of this 
Table 5. TNF- $\alpha-308 \mathrm{G}>$ A genotype distribution and insulin resistance.

\begin{tabular}{|c|c|c|c|c|}
\hline & $\begin{array}{l}\text { TNF-alpha } \\
-308 \text { G/A }\end{array}$ & $\begin{array}{c}\text { TNF-alpha } \\
\text {-308G/A }\end{array}$ & $\begin{array}{l}\text { Odds Ratio (OR) } \\
95 \% \text { Confidence }\end{array}$ & \\
\hline Insulin resistance & $G G$ & $G A+A A$ & interval CI) & P value \\
\hline \multicolumn{5}{|l|}{ Blood glucose } \\
\hline$<99 \mathrm{mg} / \mathrm{dL}$ & $24 / 36$ & $12 / 36$ & $\mathrm{OR}=0.250$ & $0.249^{b}$ \\
\hline$\geq 99 \mathrm{mg} / \mathrm{dL}$ & $8 / 9$ & $1 / 9$ & $C I: 0.028-2.237$ & \\
\hline \multicolumn{5}{|l|}{ HOMA-IR } \\
\hline$<3.16$ & $20 / 28$ & $8 / 28$ & $\mathrm{OR}=1.172$ & $0.034^{a}$ \\
\hline$\geq 3.16$ & $12 / 17$ & $5 / 17$ & CI:0.276-3.926 & \\
\hline \multicolumn{5}{|l|}{ Insulin } \\
\hline$<24.9 \mathrm{mU} / \mathrm{L}$ & $30 / 41$ & $11 / 41$ & $\mathrm{OR}=2.727$ & $0.567^{b}$ \\
\hline$\geq 24.9 \mathrm{mU} / \mathrm{L}$ & $2 / 4$ & $2 / 4$ & $C I: 0.34-21.790$ & \\
\hline
\end{tabular}

The genotypic and allelic distributions of all polymorphisms were in Hardy-Weinberg equilibrium.

${ }^{a} \div 2$ Yates corrected. ${ }^{b}$ Fisher's test exact.

variation in the promoter of the TNF- $\alpha$ gene with obesity and IR is controversial. Literature shows negative and positive reports for these associations over the last years. Different studies have evaluated the TNF- $\alpha$ gene $-308 \mathrm{G} / \mathrm{A}$ polymorphism relationship to IR and lipid abnormalities in obese children suggesting that the $-308 \mathrm{G} / \mathrm{A}$ variation in this gene does not seem to play an important role in the setting down of obesity and IR. ${ }^{17,18}$ However, an Australian study, in obese non-diabetic subjects, investigated whether a common polymorphism in the promoter region ( $(-308 \mathrm{G} / \mathrm{A})$ of the TNF- $\alpha$ gene was associated with increased risk for the development of IR. The study showed that the polymorphism was associated with increased IR in obese subjects, possibly as a result of increased TNF- $\alpha$ production. ${ }^{19}$

A study in vitro showed that the G-308A variation in the promoter region of TNF- $\alpha$ acts like a much stronger transcriptional activator than the GG (wildtype) genotype, and it is suggested that a higher transcriptional activity would result in higher TNF- $\alpha$ concentrations followed by decreased insulin sensitivity. ${ }^{20}$ Experimental studies showed three potential sites of TNF- $\alpha$ action that can mediate IR in obesity: of the regulation of free fatty acid levels, of leptin production, and of glucose transporter numbers and insulin receptor activity. ${ }^{21,22,23}$ This result represents probably the main effect of TNF- $\alpha$ in the generation of obesity-induced IR due to the importance of insulin receptor signaling in the generation of the biological actions of insulin.

Standards for IR in children have not been established. In an attempt of simplifying the measurement of insulin sensitivity, some methods using single simultaneously obtained samples of fasting insulin and glucose have been developed. The derived indexes HOMA-IR, quantitative insulin-sensitivity check index (QUICKI) and fasting glucoseto-insulin ratio (FGIR) were found to correlate well with IR. However, HOMA-IR was described as being a practical alternative for detecting IR in children due to the highly correlation with fasting insulin in children and adults. ${ }^{24}$ HOMA-IR was calculated from fasting plasma glucose and serum insulin levels, and the value of 3.16 was chosen as the cut-off point to define IR. ${ }^{13}$ A study conducted between 1999-2002 with adolescents enrolled in the National Health and Nutrition Examination Survey showed a prevalence of IR in obese children of $52.1 \%$ foreshadowing a worrisome trend on DM2 increase. ${ }^{25}$ This rate is similar to results of others studies conducted in developed countries like France, Italy, and Spain. 26,27,28 Interestingly, our findings showed a lower prevalence of IR compared to other studies. The higher levels of IR were associated with a greater degree of alterations in two criteria of the metabolic syndrome evaluated in this study. 
Although the study sample is considered small for polymorphism research in chronic metabolic diseases, an important fact is the pioneering of this study in a population of adolescents with obesity in Northeast Brazil in addition to the heterogeneity of the sample in a multiracial population.

Our results gathered evidence that $-308 \mathrm{G} / \mathrm{A}$ polymorphism of the TNF- $\alpha$ promoter can contribute to increased IR in adolescents obese with GA e AA genotypes. However, further studies are necessary to confirm, evaluate and replicate this study in other populations with obesity.

\section{Acknowledgment}

This research was supported by Unimed Aracaju - Sergipe - Brazil.

\section{References}

1. Wang HG, Yang J, Han $H, X u F$, Bian $Y$, Zhang $H$, et al. TNF- $\alpha$ G-308A polymorphism is associated with insulin resistance: a meta-analysis. Genet Mol Res. 2015;14: 56373.

2. Nossent JC, Sagen-Johnsen S, Bakland G. Tumor necrosis factor- $\alpha$ promoter $-308 / 238$ polymorphism association with less severe disease in ankylosing spondylitis is unrelated to serum TNF- $\alpha$ and does not predict TNF inhibitor response. J Rheumatol. 2014; 41:1675-82.

3. Kayser BD, ToledoCorral CM, Alderete $\mathrm{TL}$, Weigensberg MJ, Goran MI. Temporal relationships between adipocytokines and diabetes risk in Hispanic adolescents with obesity. Obesity (Silver Spring) 2015;23: 1479-85.

4. Moller DE. Potential role of TNF-alpha in the pathogenesis of insulin resistance and type 2 diabetes. Trends Endocrinol Metab. 2000;11:212-7.

5. Anusree SS, Nisha VM, Priyanka A, Raghu KG. Insulin resistance by TNF- $\alpha$ is associated with mitochondrial dysfunction in 3T3-L1 adipocytes and is ameliorated by punicic acid, a PPAR $\gamma$ agonist. Mol Cell Endocrinol. 2015; 413:1208

6. Sobti RC, Kler R, Sharma YP, Talwar KK, Singh N. Risk of obesity and type 2 diabetes with tumor necrosis factor- $\alpha$ 308G/A gene polymorphism in metabolic syndrome and coronary artery disease subjects. Mol Cell Biochm. 2012;360: 1-7.

7. Gupta V, Gupta A, Jafar T, Gupta V, Agrawal S, Srivastava $\mathrm{N}$, et al. Association of TNF- $\alpha$ promoter gene G-308A polymorphism with metabolic syndrome, insulin resistance, serum TNF- $\alpha$ and leptin levels in Indian adult women. Cytokine. 2012;57: 32-6.

8. Kelishadi R. Childhood overweight, obesity, and the metabolic syndrome in developing countries. Epidemiol Rev 2007;29:62-76.

9. Misraac A, Vikramb NK. Metabolic syndrome in children and adolescents: Problems in definition, and ethnicityrelated determinants. Diabetes \& Metabolic Syndrome: Clinical Research \& Reviews. 2007, 1:121-6.

10. Weghuber $D$, Mangge $H$, Hochbrugger E, Stulnig TM. Impact of age and metabolic syndrome on the adipokine profile in childhood and adult obesity. Exp Clin Endocrinol Diabetes 2014;122: 363-67.
11. Morandi A, Maffeis C. Predictors of metabolic risk in childhood obesity. Horm Res Paediatr (Print) 2014;82: 3-11.

12. Keskin M, Kurtoglu S, Kendirci M, Atabek ME, Yazici C. Homeostasis model assessment is more reliable than the fasting glucose/insulin ratio and quantitative insulin sensitivity check index for assessing insulin resistance among obese children and adolescents. Pediatrics 2005; 115: 500-3.

13. Sahin NM, Kinik ST. Tekindal MA. OGTT results in obese adolescents with normal HOMA-IR values. J Pediatr Endocrinol Metab. 2013; 26: 285-91.

14. Schwandt P, Kelishadi R, Ribeiro RQ, Haas GM, Poursafa P. A three-country study on the components of the metabolic syndrome in youths: the BIG Study. Int J Pediatr Obes. 2010;5:334-41.

15. Kuczmarski RJ. 2000 CDC Growth Charts for the United States: methods and development. Vital Health Stat 11 2012; 246:1-190.

16. Seitzer U, Swider C, Stüber F, Suchnicki K, Lange A, Richter $\mathrm{E}$, et. al. Tumor necrosis factor alpha promoter gene polymorphism in sarcoidosis. Cytokine 1997; 9: 787-90.

17. Bu DY, Ji WW, Bai D, Zhou J, Li HX, Yang HF. Association of polymorphisms in stress-related TNF- $\alpha$ and NPY genes with the metabolic syndrome in Han and Hui ethnic groups. Asian Pac J Cancer Prev. 2014;15: 5895-900.

18. Pyrzak B, Wisniewska A, Popko K, Demkow U, Kucharska AM. Association between anthropometric measures of obesity, metabolic disturbances and polymorphism G-308A of the tumor necrosis factor-alpha gene in children. Eur ] Med Res. 2010;15: 141-6.

19. Dalziel B, Gosby AK, Richman RM, Bryson JM, Caterson ID. Association of the TNF-alpha -308 G/A promoter polymorphism with insulin resistance in obesity. Obes Res. 2002;10: 401-7.

20. Wilson AG, Symons JA, McDowell TL, McDevitt HO, Duff GW. Effects of a polymorphism in the human tumor necrosis factor alpha promoter on transcriptional activation. Proc Natl Acad Sci. U.S.A 1997;94: 3195-9.

21. Uysal KT, Wiesbrock SM, Marino MW, Hotamisligil GS. Protection from obesity-induced insulin resistance in mice lacking TNF-alpha function. Nature. 1997;389 (6651): 610-4.

22. Uysal KT, Wiesbrock SM, Hotamisligil GS. Functional analysis of tumor necrosis factor (TNF) receptors in TNF-alphamediated insulin resistance in genetic obesity. Endocrinology 1998; 139: 4832-8.

23. Kirchgessner TG, Uysal KT, Wiesbrock SM, Marino MW, Hotamisligil GS. Tumor necrosis factor-alpha contributes to obesity-related hyperleptinemia by regulating leptin release from adipocytes. J Clin Invest. 1997;100: 2777-82.

24. Schwartz B, Jacobs DR, Moran A, Steinberger J, Hong CP, Sinaiko AR. Measurement of insulin sensitivity in children: comparison between the euglycemic-hyperinsulinemic clamp and surrogate measures. Diabetes Care. 2008;31: 783-8.

25. Lee JM, Okumura MJ, Davis MM, Herman WH, Gurney JG. Prevalence and determinants of insulin resistance among U.S. adolescents: a population-based study. Diabetes Care. 2006; 29: 2427-32.

26. Druet C, Dabbas M, Baltakse V, Payen C, Jouret B, Baud C, et al. Insulin resistance and the metabolic syndrome in obese French children. Clin Endocrinol (Oxf) 2006; 64:6728.

27. Valerio G, Licenziati MR, Iannuzzi A, Franzese A, Siani P, Riccardi G, et al. Insulin resistance and impaired glucose tolerance in obese children and adolescents from Southern Italy. Nutr Metab Cardiovasc Dis. 2006;16:279-84.

28. Ceballos LT, Siguero JPL, Ortiz AJ. Prevalence of metabolic syndrome and its components in obese children and adolescents. An Pediatr (Barc);67:352-61. 